\title{
Effect of moisture content and density on some technological properties of fiberboard
}

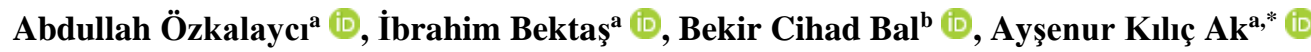

\begin{abstract}
In this study, the effect of moisture content and density of panel on some physical and mechanical properties of fiberboard was investigated. The effect of moisture and density differences on some properties of fiberboard were aimed to be revealed. The test samples were obtained from fiberboards which were divided into three different density $\left(0.590 \mathrm{~g} / \mathrm{cm}^{3}, 630\right.$ $\mathrm{g} / \mathrm{cm}^{3}$ and $\left.0.680 \mathrm{~g} / \mathrm{cm}^{3}\right)$ and moisture contents $(6 \%, 9 \%$ and $12 \%)$ groups. Within the scope of the study, physical properties such as water absorption and thickness swelling and mechanical properties such as bending strength, modulus of elasticity, internal bond strength, Janka hardness and screw holding capacity were determined. The physical and mechanical properties of the boards with different moisture and density values differed significantly. For instance, the internal bond strengths were determined as $0.34 \mathrm{~N} / \mathrm{mm}^{2}, 0.39 \mathrm{~N} / \mathrm{mm}^{2}$ and $0.62 \mathrm{~N} / \mathrm{mm}^{2}$ in the low, medium and high density groups, respectively. Respective values for moisture content groups were found $0.52 \mathrm{~N} / \mathrm{mm}^{2}, 0.45 \mathrm{~N} / \mathrm{mm}^{2}$ and $0.38 \mathrm{~N} / \mathrm{mm}^{2}$, respectively. Furthermore, the screw holding capacity which is important strength for fiberboard were determined as $15.3 \mathrm{~N} / \mathrm{mm}^{2}, 18.8 \mathrm{~N} / \mathrm{mm}^{2}$ and $25.3 \mathrm{~N} / \mathrm{mm}^{2}$ in the low, medium and high density groups, respectively. And respective values for moisture content groups were found as $19.8 \mathrm{~N} / \mathrm{mm}^{2}$, $20.1 \mathrm{~N} / \mathrm{mm}^{2}$ and $19.4 \mathrm{~N} / \mathrm{mm}^{2}$, respectively. In the samples belonging to the same moisture group, high mechanical properties at low moisture content and low mechanical properties at high moisture content were obtained. Research results revealed that the mechanical properties increased in parallel with the increase in density. Physical and mechanical properties of MDF boards change as the board density increases. Generally, as the board density increased, all mechanical properties increased. However, with the increase in moisture percentage, the mechanical properties of the boards decreased.
\end{abstract}

Keywords: Fiberboard, Physical properties, Mechanical properties

\section{Lif levhanın bazı teknolojik özellikleri üzerine rutubet miktarı ve yoğunluğun etkisi}

Özet: Bu çalışmada, rutubet ve yoğunluk farklılıklarının, liflevhanın bazı fiziksel ve mekanik özellikleri üzerine etkisinin ortaya konması amaçlanmıştır. Araştırmada kullanılan test numuneleri, üç farklı yoğunluk grubuna $\left(0.590 \mathrm{~g} / \mathrm{cm}^{3}, 0.630 \mathrm{~g} / \mathrm{cm}^{3}\right.$ ve 0.680 $\left.\mathrm{g} / \mathrm{cm}^{3}\right)$ ve üç farklı rutubet derecesine (\%6, \%9 ve \%12) ayrılan lif levhalardan elde edilmiştir. Çalışma kapsamında, su alma ve kalınlığına șişme gibi fiziksel özellikler ile eğilme direnci, eğilmede elastikiyet modülü, iç yapışma kuvveti, Janka sertlik ve vida tutma kapasitesi gibi mekanik özellikler belirlenmiştir. Farklı rutubet ve yoğunluk değerlerine sahip levhaların fiziksel ve mekanik özellikleri önemli ölçüde farklılık göstermiştir. Levhaların yüzeye dik çekme direnci düşük yoğunluk grubunda 0.34 $\mathrm{N} / \mathrm{mm}^{2}$, orta yoğunluk grubunda $0.39 \mathrm{~N} / \mathrm{mm}^{2}$, yüksek yoğunluk grubunda $0.62 \mathrm{~N} / \mathrm{mm}^{2}$ olarak tespit edilmiştir. Rutubet miktarlarına göre kıyaslandığında ise düşük rutubetten yüksek rutubete doğru sırası ile $0.52 \mathrm{~N} / \mathrm{mm}^{2}, 0.45 \mathrm{~N} / \mathrm{mm}^{2}$ ve $0.38 \mathrm{~N} / \mathrm{mm}^{2}$ bulunmuş̧tur. Yine, MDF için önemli dirençlerden vida tutma direnci düşük yoğunluk grubunda $15.3 \mathrm{~N} / \mathrm{mm}^{2}$, orta yoğunluk grubunda $18.8 \mathrm{~N} / \mathrm{mm}^{2}$ ve yüksek yoğunluk grubunda $25.3 \mathrm{~N} / \mathrm{mm}^{2}$ olarak belirlenmiştir. Aynı şekilde, rutubet grupları için de düşük rutubette $19.8 \mathrm{~N} / \mathrm{mm}^{2}$, orta rutubette $20.1 \mathrm{~N} / \mathrm{mm}^{2}$ ve yüksek rutubette $19.4 \mathrm{~N} / \mathrm{mm}^{2}$ değerleri elde edilmiştir. Yine, MDF için önemli dirençlerden vida tutma direnci testlerinde yoğunluk grupları için değerler, LD: 15.3, MD: 18.8 ve HD: $25.3 \mathrm{~N} / \mathrm{mm}^{2}$ olarak ölçüldü. Aynı şekilde, rutubet grupları için de, LM: 19.8, MM: 20.1 ve HM: $19.4 \mathrm{~N} / \mathrm{mm}^{2}$ değerleri elde edilmiştir. Aynı rutubet grubuna ait numunelerde, düşük nem içeriğginde yüksek mekanik özellikler ve yüksek nem içeriğinde düşük mekanik özellikler elde edilmiştir. Araştırma sonuçları, mekanik özelliklerin yoğunluktaki artışa paralel olarak arttığını ortaya koymuştur. MDF levhaların, fiziksel ve mekanik özellikleri levha yoğunluğu arttıkça değişmektedir. Genel olarak, levha yoğunluğu arttıkça, tüm mekanik özellikler artmıştır. Fakat, rutubet yüzdesindeki artışla levhaların mekanik özellikleri azalmıştır.

Anahtar kelimeler: Lif levha, Fiziksel özellikler, Mekanik özellikler

\section{Introduction}

In the past, wood-based boards, such as chipboard and fiberboard, were produced by some manufacturers operating in different countries. The density values of the boards produced by these producers showed little difference. Today, the number of companies operating in this sector has increased rapidly. As a natural consequence, the densities of

\footnotetext{
$\bowtie$ a Kahramanmaras Sutcu Imam University, Faculty of Forestry, Department of Forest Industry Engineering, Kahramanmaras, Turkey

b Kahramanmaras Sutcu Imam University, Vocational School of Technical Sciences, Kahramanmaras, Turkey

@ * Corresponding author (İletişim yazarı): aysenurkilic89@ gmail.com

$\checkmark \quad$ Received (Geliş tarihi): 03.12.2020, Accepted (Kabul tarihi): 17.05.2021
}

Citation (Atıf): Özkalaycı, A., Bektaş, İ., Bal, B.C., Kılıç Ak, A., 2021. Effect of moisture content and density on some technological properties of fiberboard. Turkish Journal of Forestry, 22(2): 128-134. DOI: $10.18182 /$ tjf.834279 
wood-based boards on the market have gained a wide variety. The aesthetic, physical and mechanical properties of these boards are important in usage areas. Particularly, the density of the board effects its mechanical properties highly. In addition, moisture content is an important factor effecting the board form and its durability.

In the literature, some studies have been carried out on the physical and mechanical properties of fiberboard. In these studies, effects of board thickness (Istek et al., 2015), board density (Ozen, 1975), used fiber properties (Park et al., 2001; Ayrilmis, 2002), pres time and press temperature (Li et al., 2009) or glues (Park et al., 2001) on board properties were investigated.

The measured and calculated values showed that the resistance against removal of wood screws, embedded in the wood material, is mainly dependent on the screw diameter and material density. Strength values increase with the increasing density of the material. With increasing diameter, embedment depth of screw, and density of the material the axial stiffness of the joint is increasing (Joščák et al., 2014).

Istek et al. (2015) investigated the properties of commercial medium density fiberboard (MDF) of different thicknesses used in furniture production. According to the findings; it was determined that physical and mechanical properties changed as the board thickness increased.

Ganev et al., (2007) studied on the effect of moisture content and density of MDF on modulus of elasticity E1, E3, shear modulus, G13, and Poisson's ratios 012 and 013. Parameters density was determined from panels without density profile with average density levels of $540 \mathrm{~kg} / \mathrm{m}^{3}$, $650 \mathrm{~kg} / \mathrm{m}^{3}$, and $800 \mathrm{~kg} / \mathrm{m}^{3}$. The relation with moisture content was determined from samples conditioned at $50 \%$, $65 \%$, and $80 \%$ relative humidity. While panels E1, E3, and G13 decreased with the increase of moisture content, they increased with the increase in density. At each nominal density level, the values of E1 were much higher than the values of G13. Also, the effect of moisture content and density on the Poisson's ratios was not significant.

Ayrilmis (2002) investigated the effect of tree species on mechanical properties of MDF manufactured from furnishes of oak, beech, pine (Pinus nigra), and a mixture of these species. Tests were made on specimens conditioned at $20 \pm 2{ }^{\circ} \mathrm{C}$ and $65 \pm 5 \%$ relative humidity. According to the, it was determined that tree species affects mechanical properties of the panels. Similar results were obtained by Akgul and Camlibel (2008) using R. ponticum L., Pinus sylvestris L. and Quercus robur L. biomass.

Today, wood raw material is used intensively in fiberboard production. In addition, it was determined by scientific researches that fiberboard can be produced from some annual plants and natural fibers as well. For example, Rashid et al. (2014) determined that both physical and mechanical properties of MDF produced with natural fibers obtained from leaf and stem fibers of banana plant were better than commercial MDF except water absorption. Similar results were obtained from MDF produced from sugar cane fiber by Ashori et al. (2009).

The effects of two different silane and paraffin on the physical and mechanical properties of the boards were investigated by Ozsoylu (2018). According to the obtained data, water absorption and thickness swelling rates improved with the use of additional agents. For internal bond strength and modulus of elasticity values, there was an increase in the use of the additive compared to the control sample.

The moisture content of the fiberboards not only effects the physical and mechanical properties but also the electrical conduction and thermal properties. In a study conducted by Zhou et al. (2013), it was reported that electrical and thermal conduction increased with the increase of board moisture. In another study, it was determined that the board surface roughness increased with the increasing of board moisture but adhesion strength decreased (Ozdemir et al., 2009).

In the literature, there are many studies on the factors effecting the technological properties of fiberboards. However, the effect of board density and moisture on technological properties have not been completely introduced. Therefore, in this study, the effect of board moisture and density on the physical and mechanical properties of fiberboard was investigated.

\section{Material and method}

The boards used in the preparation of the test samples were supplied from the same source in order to avoid differences in the structural properties. Fiberboards with 3 different densities were obtained from the market by purchase.

The fiberboards used in the tests were parted in three groups as low density (LD:0.590 $\mathrm{g} / \mathrm{cm}^{3}$ ), medium density (MD:0.630 g/ $\mathrm{cm}^{3}$ ) and high density (HD:0.680 $\mathrm{g} / \mathrm{cm}^{3}$ ) according to their densities. 30 test samples were prepared for each density group and totally 90 samples were tested. At the same time, the test samples were separated into three different moisture groups. These are low moisture content (LMC:6\%), medium moisture content (MMC:9\%) and high moisture content (HMC:12\%). As in the density groups, 30 samples were prepared in each moisture group and a total of 90 samples were tested. Moisture of the test samples were tried to be adjusted to the moisture content of $6,9,12 \%$ by applying different temperature and moisture conditions in the air conditioner cabinet. For $6 \%$ moisture content, air conditioner cabinet (Nuve TK 252) were adjusted $20 \pm 2^{\circ} \mathrm{C}$ $30 \pm 5 \%$ relative humidity. Cabinet settings were changed to $20 \pm 2{ }^{\circ} \mathrm{C}-50 \pm 5 \%$ and $20 \pm 2^{\circ} \mathrm{C}-65 \pm 5 \%$ for $9 \%$ and $12 \%$ moisture content, respectively (Kantay, 1993). Thus, the samples were provided to reach the desired humidity levels.

The physical and mechanical properties were determined according to the relevant standards, as follows; moisture content (TS EN 322), density (TS EN 323), water absorption- thickness swelling (TS EN 317), modulus of rupture and modulus of elasticity (TS EN 310), internal bond strength (TS EN 319), janka hardness (TS 2479), screw holding capacity (TS EN 13446).

\section{Results and discussion}

The results of the analysis of the effect of density and moisture content differences on the water absorption percentages of the boards obtained from fiberboards are shown in Table 1.

According to the results of the analysis of variance given in Table 1, it is seen that the effect of density, moisture and densitymoisture together on the water absorption values calculated in fiberboard samples compose significant differences at $p<0.001$ level. The multiple-range test 
Table 3. Modulus of elasticity

\begin{tabular}{|c|c|c|c|c|c|c|c|}
\hline & Groups $^{(*)}$ & Number of sample & Mean $\left(\mathrm{N} / \mathrm{mm}^{2}\right)$ & Standard deviation & Standard error & \multicolumn{2}{|c|}{ Coefficient of variation (\%) } \\
\hline \multirow{4}{*}{ Density } & LD & 90 & $1725.1 \mathrm{a}^{(* *)}$ & 330.94 & 34.88 & \multicolumn{2}{|c|}{19.18} \\
\hline & MD & 90 & $1898.9 b$ & 529.50 & 55.81 & \multicolumn{2}{|c|}{27.89} \\
\hline & HD & 90 & $2641.5 c$ & 562.97 & 59.34 & \multicolumn{2}{|c|}{21.31} \\
\hline & Total & 270 & 2088.5 & 626.41 & 38.12 & \multicolumn{2}{|c|}{29.99} \\
\hline \multirow{4}{*}{ Moisture } & LM & 90 & $2624.2 \mathrm{a}$ & 559.87 & 59.02 & \multicolumn{2}{|c|}{21.33} \\
\hline & MM & 90 & $2081.1 b$ & 443.71 & 46.77 & \multicolumn{2}{|c|}{21.32} \\
\hline & HM & 90 & $1560.1 \mathrm{c}$ & 320.99 & 33.84 & \multicolumn{2}{|c|}{20.57} \\
\hline & Total & 270 & 2088.5 & 626.41 & 38.12 & \multicolumn{2}{|c|}{29.99} \\
\hline \multicolumn{8}{|c|}{- Analysis results of variance -} \\
\hline \multicolumn{4}{|c|}{ Sum of squares } & df & Meansquare & \multicolumn{2}{|c|}{$\begin{array}{ll}\mathrm{F} & \text { Sig. } \\
\end{array}$} \\
\hline \multicolumn{2}{|r|}{ Density } & \multicolumn{2}{|c|}{42640000} & 2 & 21320000 & \multirow{2}{*}{$\begin{array}{r}938.718 \\
1121.825\end{array}$} & 0.000 \\
\hline \multicolumn{2}{|c|}{ Moisture } & & 50960000 & 2 & 25480000 & & 0.000 \\
\hline \multicolumn{2}{|c|}{ Density $*$ Moisture } & & 6016889 & 4 & 1504222.326 & $\begin{array}{r}1121.825 \\
66.224\end{array}$ & 0.000 \\
\hline
\end{tabular}

(LD:0.590 gr/ $/ \mathrm{cm}^{3}, \mathrm{MD}: 0.630 \mathrm{gr} / \mathrm{cm}^{3}$ and HD:0.680 gr/ $\left./ \mathrm{cm}^{3}\right) ;{ }^{* *}$ Means with the same lower case letter are not significantly different in Duncan's mean separation test.

According to the results of the variance analysis of modulus of elasticity included in the same Table, the interaction of density, moisture and density-moisture factors on the fiberboard test samples were found to be statistically significant on the modulus of elasiticty $(p<0.001)$. Similarly, the mean values of LD (1725.1 N/mm²), MD (1898.9 $\left.\mathrm{N} / \mathrm{mm}^{2}\right)$ and HD $\left(2641.5 \mathrm{~N} / \mathrm{mm}^{2}\right)$ samples and the mean values of the LM $\left(2624.2 \mathrm{~N} / \mathrm{mm}^{2}\right), \mathrm{MM}\left(2081.1 \mathrm{~N} / \mathrm{mm}^{2}\right.$ and HM $\left(1560.1 \mathrm{~N} / \mathrm{mm}^{2}\right)$ groups were found to be significantly different from each other as can be seen in the Duncan test results shown in Table 3.

It can be seen from Table 3, the modulus of elasticity values increase in direct proportion to the density but decreasing inversely with moisture. According to the results of variance analysis of the modulus of elasticity included in the same table; density, moisture and the interaction of density-moisture factors on the fiberboard test samples were found to be statistically significant $(p<0.001)$ on the modulus of elasticity. Similarly, the Duncan test results in the Table reveal the existence of significant differences in mean values of LD $\left(1725.1 \mathrm{~N} / \mathrm{mm}^{2}\right)$, MD $\left(1898.9 \mathrm{~N} / \mathrm{mm}^{2}\right)$ and HD $\left(2641.5 \mathrm{~N} / \mathrm{mm}^{2}\right)$ samples as well as mean values of LM $\left(2624.2 \mathrm{~N} / \mathrm{mm}^{2}\right), \mathrm{MM}\left(2081.1 \mathrm{~N} / \mathrm{mm}^{2}\right)$ and HM (1560.1 $\mathrm{N} / \mathrm{mm}^{2}$ ) groups compared to each other. Yet, when the density and moisture groups are evaluated according to the range, it can be said that the density range (HD-LD:916.4 $\mathrm{N} / \mathrm{mm}^{2}$ ) is narrower than the moisture samples (HMLM:1064.1 N/mm²).

In general, wood based boards are effected by density and moisture like solid wood. Namely, as the density of the solid wood increases, its mechanical properties increase (Kollmann and Cote, 1968; Bozkurt and Göker, 1996; Örs and Keskin, 2001). In the literature, a similar behavior was also found in wood based boards (Istek et al., 2015).

Findings of bending strength obtained from laboratory experiments are given in Table 4.

When the results of the analyzes are considered in terms of the effects of densities, it will be seen that the density constitutes significant differences on the bending strength $(p<0.001)$. Same evaluations are also valid for the effect of moisture on bending strength. At the same time, the combined effect of density and moisture on the bending strength also made a difference in $p<0.01$ significance level.
The results of the Duncan test given in Table 4 show that there are significant differences between the three density groups in terms of bending strength values (19.3, 21.6 and $29.1 \mathrm{~N} / \mathrm{mm}^{2}$, for $\mathrm{LD}, \mathrm{MD}$ and $\mathrm{HD}$, respectively). Besides, there was no difference between LM $\left(23.8 \mathrm{~N} / \mathrm{mm}^{2}\right)$ and MM $\left(23.8 \mathrm{~N} / \mathrm{mm}^{2}\right)$ groups according to Duncan test, while significant differences were determined between these two groups and HM $\left(22.3 \mathrm{~N} / \mathrm{mm}^{2}\right)$. According to the results of Duncan analysis, it can be said that the differences between MD and HD in density groups as well as MM and HM in moisture groups are more obvious. In previous studies on the mechanical properties of MDF boards, it has been reported that the bending strength increases as the board density increase (Ozen, 1975; Istek et al., 2015).

Table 5 revealed that density, moisture and together both have significant differences on the internal bond strength. The internal bond strength measured in the fiberboard samples were $0.34 \mathrm{~N} / \mathrm{mm}^{2}$ in LD, $0.39 \mathrm{~N} / \mathrm{mm}^{2}$ in MD and $0.62 \mathrm{~N} / \mathrm{mm}^{2}$ in HD; $0.52 \mathrm{~N} / \mathrm{mm}^{2}$ for $\mathrm{LM}, 0.45 \mathrm{~N} / \mathrm{mm}^{2}$ for $\mathrm{MM}$ and $0.38 \mathrm{~N} / \mathrm{mm}^{2}$ for $\mathrm{HM}$.

From the results of the Duncan test applied to the specimens internal bond strength, it can be seen in Table 5 that the density and humidity have significant differences between these strength values. In previous studies, it was determined that the internal bond strength increased in parallel with the increase in density (Ozen, 1975).

The results of the data obtained in the screw withdrawal tests performed on the fiberboard samples are shown in Table 6. According to the results of variance analysis, density, moisture and density-moisture interaction were found to be significantly effective on screw withdrawal strength.

Comparing the mean values of density and moisture groups given in the same Table, while LD, MD and HD are completely different from each other, as for the moisture groups noteworthy differences are only found between MM and HM. In a study on the screw withdrawal stregth of MDF boards, it was reported that the increase in density also increased the screw holding strength (Vassillou and Barboutis, 2005). In addition, similar findings were found by Joščák et al. (2014). 
Table 4. Modulus of rupture

\begin{tabular}{|c|c|c|c|c|c|c|c|}
\hline & Groups $^{(*)}$ & Number of sample & Mean $\left(\mathrm{N} / \mathrm{mm}^{2}\right)$ & Standard deviation & Standard error & \multicolumn{2}{|c|}{ Coefficient of variation $(\%)$} \\
\hline \multirow{4}{*}{ Density } & LD & 90 & $19.3 \mathrm{a}^{(* *)}$ & 3.081 & 0.325 & \multicolumn{2}{|c|}{15.96} \\
\hline & MD & 90 & $21.6 b$ & 1.818 & 0.192 & \multicolumn{2}{|c|}{8.43} \\
\hline & HD & 90 & $29.1 \mathrm{c}$ & 1.567 & 0.165 & \multicolumn{2}{|c|}{5.39} \\
\hline & Total & 270 & 23.3 & 4.753 & 0.289 & \multicolumn{2}{|c|}{20.39} \\
\hline \multirow{4}{*}{ Moisture } & LM & 90 & $23.8 \mathrm{a}$ & 4.413 & 0.465 & \multicolumn{2}{|c|}{18.55} \\
\hline & MM & 90 & $23.8 \mathrm{a}$ & 5.167 & 0.545 & \multicolumn{2}{|c|}{21.70} \\
\hline & $\mathrm{HM}$ & 90 & $22.3 b$ & 4.544 & 0.479 & \multicolumn{2}{|c|}{20.35} \\
\hline & Total & 270 & 23.3 & 4.753 & 0.289 & \multicolumn{2}{|c|}{20.39} \\
\hline \multicolumn{8}{|c|}{ - Analysis results of variance - } \\
\hline \multicolumn{4}{|c|}{ Sum of squares } & df & Meansquare & $\mathrm{F}$ & Sig. \\
\hline \multicolumn{2}{|r|}{ Density } & \multicolumn{2}{|c|}{4718.289} & 2 & 2359.144 & 537.949 & \multirow{2}{*}{537.949} \\
\hline \multicolumn{2}{|c|}{ Moisture } & \multicolumn{2}{|r|}{129.089} & 2 & 64.544 & \multirow{2}{*}{$\begin{array}{r}14.718 \\
4.782\end{array}$} & \\
\hline \multicolumn{2}{|c|}{ Density * Moisture } & \multicolumn{2}{|r|}{83.889} & 4 & 20.972 & & 0.001 \\
\hline
\end{tabular}

${ }^{*}$ LD, MD and HD's mean values were given for all moisture groups (LM:6\%, MD:9\%, HM:12\%); also LM, MM and HM mean values were given all density groups (LD:0.590 gr/ $\mathrm{cm}^{3}, \mathrm{MD}: 0.630 \mathrm{gr} / \mathrm{cm}^{3}$ and HD:0.680 gr/ $\left./ \mathrm{cm}^{3}\right) ;{ }^{* *}$ Means with the same lower case letter are not significantly different in Duncan's mean separation test.

Table 5. Internal bond strength

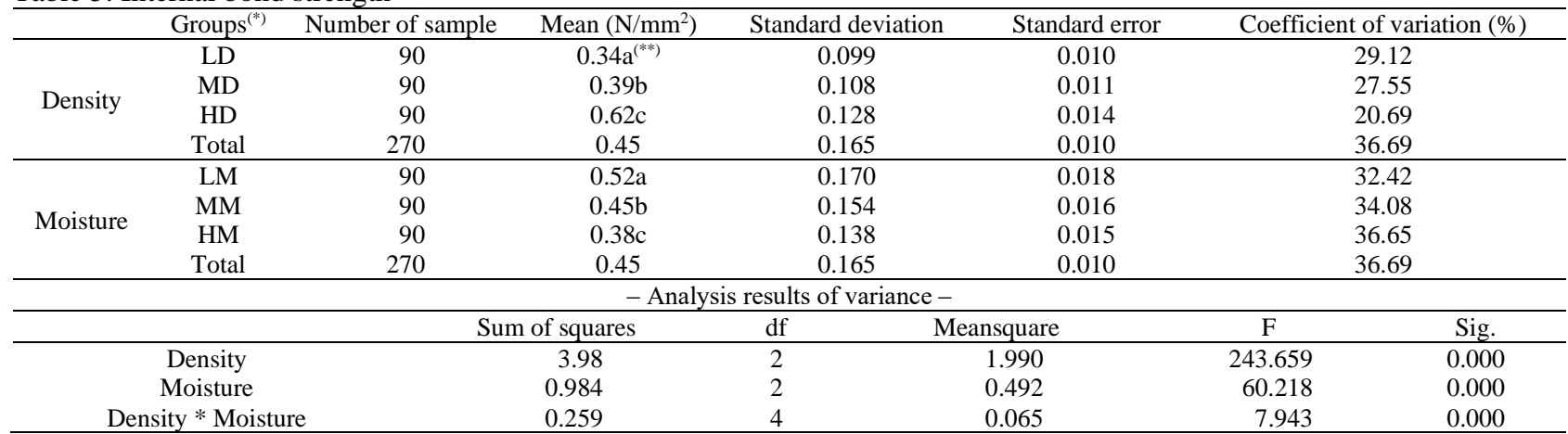

${ }^{*}$ LD, MD and HD's mean values were given for all moisture groups (LM:6\%, MD:9\%, HM:12\%); also LM, MM and HM mean values were given all density groups (LD:0.590 gr/ $/ \mathrm{cm}^{3}$, MD:0.630 gr/ $\mathrm{cm}^{3}$ and HD:0.680 gr/ $\left./ \mathrm{cm}^{3}\right) ;{ }^{* *}$ Means with the same lower case letter are not significantly different in Duncan's mean separation test.

Table 6. Screw withdrawal strength

\begin{tabular}{|c|c|c|c|c|c|c|c|}
\hline & Groups $^{(*)}$ & Number of sample & Mean $\left(\mathrm{N} / \mathrm{mm}^{2}\right)$ & Standard deviation & Standard error & \multicolumn{2}{|c|}{ Coefficient of variation $(\%)$} \\
\hline \multirow{4}{*}{ Density } & LD & 90 & $15.3 \mathrm{a}^{(* *)}$ & 1.950 & 0.206 & \multicolumn{2}{|c|}{12.73} \\
\hline & MD & 90 & $18.8 b$ & 1.159 & 0.122 & \multicolumn{2}{|c|}{6.16} \\
\hline & HD & 90 & $25.3 \mathrm{c}$ & 1.319 & 0.139 & \multicolumn{2}{|c|}{5.22} \\
\hline & Total & 270 & 19.8 & 4.397 & 0.268 & \multicolumn{2}{|c|}{22.21} \\
\hline \multirow{4}{*}{ Moisture } & LM & 90 & $19.8 \mathrm{ab}$ & 4.227 & 0.446 & \multicolumn{2}{|c|}{21.31} \\
\hline & MM & 90 & $20.1 \mathrm{a}$ & 4.478 & 0.472 & \multicolumn{2}{|c|}{22.29} \\
\hline & HM & 90 & $19.4 b$ & 4.508 & 0.475 & \multicolumn{2}{|c|}{23.16} \\
\hline & Total & 270 & 19.8 & 4.397 & 0.268 & \multicolumn{2}{|c|}{22.21} \\
\hline \multicolumn{8}{|c|}{- Analysis results of variance -} \\
\hline \multicolumn{4}{|c|}{ Sum of squares } & \multicolumn{2}{|c|}{ df $\quad$ Meansquare } & $\mathrm{F}$ & Sig. \\
\hline \multicolumn{2}{|r|}{ Density } & \multicolumn{2}{|c|}{4588.708} & \multicolumn{2}{|c|}{2294.354} & 1095.305 & 0.000 \\
\hline \multicolumn{2}{|r|}{ Moisture } & \multicolumn{2}{|c|}{18.146} & \multicolumn{2}{|c|}{9.073} & 4.331 & 0.014 \\
\hline & sity * Moisture & \multicolumn{2}{|c|}{47.943} & \multicolumn{2}{|c|}{11.986} & 5.722 & 0.000 \\
\hline
\end{tabular}

${ }^{*}$ LD, MD and HD's mean values were given for all moisture groups (LM:6\%, MD:9\%, HM:12\%); also LM, MM and HM mean values were given all density groups (LD:0.590 gr/ $\mathrm{cm}^{3}, \mathrm{MD}: 0.630 \mathrm{gr} / \mathrm{cm}^{3}$ and HD:0.680 gr/ $/ \mathrm{cm}^{3}$ ); ${ }^{* *}$ Means with the same lower case letter are not significantly different in Duncan's mean separation test.

Data and analysis results belonging to Janka hardness measurements are given in Table 7.

From this table, according to the data of variance analysis made to determine the effect of density and moisture differences on fiberboard Janka hardness samples, it can be said that density, moisture and both have a significant effect on Janka hardness samples. Again, by comparing the average Janka hardness values of density and moisture groups, there were significant differences between the averages in both factors. Especially the difference between MD $\left(32.8 \mathrm{~N} / \mathrm{mm}^{2}\right)$ and $\mathrm{HD}\left(45.1 \mathrm{~N} / \mathrm{mm}^{2}\right)$ groups is quite high compared to other groups. From these data, it can be said that Janka hardness value is more effected by density than moisture differences. In a study conducted by Ozen (1975), it was reported that the hardness value increased as the density of the fiberboard increased and the moisture content decreased. 
Table 7. Janka hardness

\begin{tabular}{|c|c|c|c|c|c|c|c|}
\hline & Groups $^{(*)}$ & Number of sample & Mean $\left(\mathrm{N} / \mathrm{mm}^{2}\right)$ & Standard deviation & Standard error & \multicolumn{2}{|c|}{ Coefficient of variation $(\%)$} \\
\hline \multirow{4}{*}{ Density } & LD & 90 & $28.0 \mathrm{a}^{(* *)}$ & 2.812 & 0.296 & \multicolumn{2}{|c|}{10.04} \\
\hline & MD & 90 & $32.8 \mathrm{~b}$ & 3.617 & 0.381 & \multicolumn{2}{|c|}{11.03} \\
\hline & $\mathrm{HD}$ & 90 & $45.1 \mathrm{c}$ & 4.253 & 0.448 & \multicolumn{2}{|c|}{9.43} \\
\hline & Total & 270 & 35.3 & 8.055 & 0.490 & \multicolumn{2}{|c|}{22.82} \\
\hline \multirow{4}{*}{ Moisture } & LM & 90 & $39.1 \mathrm{a}$ & 8.483 & 0.894 & \multicolumn{2}{|c|}{21.69} \\
\hline & MM & 90 & $35.3 b$ & 7.060 & 0.744 & \multicolumn{2}{|c|}{19.99} \\
\hline & $\mathrm{HM}$ & 90 & $31.5 \mathrm{c}$ & 6.685 & 0.705 & \multicolumn{2}{|c|}{21.25} \\
\hline & Total & 270 & 35.3 & 8.055 & 0.490 & \multicolumn{2}{|c|}{22.82} \\
\hline \multicolumn{8}{|c|}{- Analysis results of variance -} \\
\hline \multicolumn{4}{|c|}{ Sum of squares } & df $\quad \mathrm{M}$ & Meansquare & $\mathrm{F}$ & Sig. \\
\hline \multicolumn{2}{|r|}{ Density } & \multicolumn{2}{|c|}{13976.27} & 2 & 6988.136 & 2768.021 & 0.000 \\
\hline \multirow{2}{*}{\multicolumn{2}{|c|}{$\begin{array}{c}\text { Moisture } \\
\text { Density * Moisture }\end{array}$}} & \multicolumn{2}{|c|}{2635.844} & 2 & 1317.922 & 522.033 & 0.000 \\
\hline & & \multicolumn{2}{|c|}{183.044} & 4 & 45.761 & 18.126 & 0.000 \\
\hline
\end{tabular}

(LD:0.590 gr/ $/ \mathrm{cm}^{3}, \mathrm{MD} \cdot 0.630 \mathrm{gr} / \mathrm{cm}^{3}$ and $\mathrm{HD} \cdot 0.680 \mathrm{gr} / \mathrm{cm}^{3}$ ): ${ }^{*}$ Means with the same lower case letter are not significantly different in Duncan's mean separation test.

\section{Conclusion}

In this study, the effect of board moisture and density on the physical and mechanical properties of the fiberboard was investigated on commercially produced boards. According to the obtained findings, the following results can be said;

- In commercially produced MDF boards, physical and mechanical properties vary as the board density increases. When the density of the boards increased from $590 \mathrm{~kg} / \mathrm{m}^{3}$ to $680 \mathrm{~kg} / \mathrm{m}^{3}$, it was determined that the percentage of water absorption decreased, but thickness swelling increased. In addition, the percentage of water absorption was decreased when the moisture increased from $6 \%$ to $12 \%$.

- Generally, as the board density increased, all mechanical properties increased. However, mechanical properties of boards decreased with the increase in the moisture percentage. According to the ANOVA test F values, the effect of density on mechanical properties is higher than the effect of moisture.

- As a result, the degree of interactions between density and moisture content during the use of MDF in various areas has been revealed in this study. Hereat, some landmarks have been identified as to how the basic properties of the material will change between density and moisture content. With this aspect, the findings obtained in the study will be able to make a different contribution to the literature. At the same time, it is likely that this contribution will provide additional benefits for the areas of use.

\section{Acknowledgement}

The authors would like t1 express their gratitude to the KSUBAP (The Scientific Research Projects Unit of Kahramanmaras Sütcü Imam University) No: 2017/1-59YLS for its financial support.

\section{References}

Akgul, M. Camlibel, O., 2008. Manufacture of medium density fiberboard (MDF) panels from rhododendron (R. ponticum $L$.) biomass. Building and Environment, 43(4): 438-443. https://doi.org/10.1016/j.buildenv.2007.01.003

Ashori, A., Nourbakhsh, A., Karegarfard, A., 2009. Properties of medium density fiberboard based on bagasse fibers. Journal of Composite $\quad$ Materials, 43(18): $1927-1934$. DOI: $10.1177 / 0021998309341099$

Ayrilmis, N., 2002. Effect of tree species on some mechanical properties of MDF. İstanbul Üniversitesi Orman Fakültesi Dergisi, 1(52): 125-146.

Ayrilmis, N., 2007. Effect of panel density on dimensional stability of medium and high-density fiberboards. Journal of Materials Science, 42(20): 8551-8557. DOI: 10.1007/s10853-007-17828

Ayrilmis, N., Laufenberg, T.L., Winandy, J.E., 2009. Dimensional stability and creep behavior of heat-treated exterior medium density fiberboard. European Journal of Wood and Wood Products, 67(3): 287-295. DOI 10.1007/s00107-009-0311-7

Bozkurt, Y., Göker, Y., 1996. Fiziksel ve Mekanik Ağaç Teknolojisi, İstanbul Üniversitesi Orman Fakültesi Yayınları, No: 3944, Istanbul.

Ganev, S., Gendron, G., Cloutier, A., Beauregard, R., 2007. Mechanical properties of MDF as a function of density and moisture content. Wood and Fiber Science, 37(2): 314-326.

Istek, A., Mugla, K., Yazici, H., 2015. Mobilya üretiminde kullanılan ticari mdf levhaların özellikleri. Selçuk-Teknik Dergisi, 14(2): 333-343.

Joščák, P., N., Langová, N. Tvrdovský, M., 2014. Withdrawal resistance of wood screw in wood-based materials. Forestry and Wood Technology, 87: 90-96.

Kantay, R. 1993. Kereste Kurutma ve Buharlama. Ormanc1lik Eğitim ve Kültür Vakfı Yayın No: 6, Istanbul, Turkey.

Kollmann, F., Cote, W.A., 1968. Principles of Wood Science and Technology, Springer Verlag.

Li, X., Li, Y., Zhong, Z., Wang, D., Ratto, J.A., Sheng, K., Sun, X.S., 2009. Mechanical and water soaking properties of medium density fiberboard with wood fiber and soybean protein adhesive. Bioresource Technology, 100(14): 35563562. https://doi.org/10.1016/j.biortech.2009.02.048

Ors, Y., Keskin, H., 2001. Ağaç Malzeme Bilgisi. Gazi Üniversitesi Ders Kitabı, Ankara.

Ozdemir, T., Hiziroglu, S., Malkocoglu, A., 2009. Influence of relative humidity on surface quality and adhesion strength of coated medium density fiberboard (MDF) panels. Materials\&Design, 30(7): 2543-2546. DOI: $10.1016 /$ j.matdes.2008.09.036

Ozen, R., 1975. Lif levhalarının fiziksel ve mekanik özellikleri ve bunlara tesir eden faktörler. İstanbul Üniversitesi Orman Fakültesi Dergisi, 25(2): 49-84. 
Ozlusoylu, S., 2018. Effects of silane and paraffin used on properties in fiber board production. Master's Thesis, Bartin University, Institute of Science and Technology, Bartin.

Park, B.D., Kim, Y.S., Riedl, B., 2001. Effect of wood-fiber characteristics on medium density fiberboard (MDF) performance. Journal of the Korean Wood Science and Technology, 29(3): 27-35

Rashid, M.M., Das, A.K., Shams, M.I., Biswas, S.K., 2014. Physical and mechanical properties of medium density fiber board (MDF) fabricated from banana plant (Musa sapientum) stem and midrib. Journal of the Indian Academy of Wood Science, 11(1): 1-4. DOI 10.1007/s13196-014-0109-z

TS EN 2479, 2005. Wood-determination of static hardness. TSE, Ankara.

TS EN 310, 1999. Wood-based panels-determination of modulus of elasticity in bending and of bending strengt. TSE, Ankara.

TS EN 317, 1999. Particleboards and fibreboards-determination of swelling in thickness after immersion in water. TSE, Ankara.
TS EN 319, 1999. Particleboards and fibreboards- determination of tensile strength perpendicular to the plane of the board. TSE, Ankara.

TS EN 322, 1999. Wood-based panels- determination of moisture content. TSE, Ankara.

TS EN 323, 1999. Wood-based panels- determination of density. TSE, Ankara.

TS EN 13446, 2005. Wood-based panels- determination of withdrawal capasity of fasteners. TSE, Ankara.

Vassiliou, V., Barboutis, I., 2005. Screw withdrawal capacity used in the eccentric joints of cabinet furniture connectors in particleboard and MDF. Journal of Wood Science, 51(6): 572576. DOI 10.1007/s10086-005-0708-9

Zhou, J., Zhou, H., Hu, C., Hu, S., 2013. Measurements of thermal and dielectric properties of medium density fiberboard with different moisture content. BioResources, 8(3): 4185-4192. 